spiralization is brought about by the spread or diffusion of the contraction stimulus through the cytoplasmic 'matrix' and would be facilitated, and possibly directed", by sub-fibrillar connexions if they should be shown to exist. The point that bears emphasis, however, is the suggestion that the same propagated disturbance may result in a two-dimensional vibration proximally and a three-dimensional spiral distally. In this respect, a torsional wave always accompanies the bending wave. Any decrease in the resistance or compressibility of the distal region of the tail would tend to increase the three-dimensional lashing of that portion of the flagellum.
${ }^{1}$ Gray, J., J. Exp. Biol., 82, 775 (1955).

${ }^{2}$ Gray, J., J. Exp. Biol., 25,96 (1958).

${ }^{3}$ Fawcett, D. W., and Porter, K. K., J. Morphol., 94, 221 (1951).

4 Afzelius, B., J. Biophys. Biochem. Cytol, (in the press).

${ }^{5}$ Bishop, D. W., Fed. Proc., 17 (Pt. 1), 15 (1958).

- Szent-Györgyi, A., Biol. Bull., 86, 140 (1949).

7 Hoffmann-Berling, H., Biochim. Biophys, Acta, 16, 146 (1953).

8 Rothschild, Lord, Endeavour, 16, 79 (1956).

- Bradfleld, J. R. G., Symp. Soc. Exp. Biol., 9, 306 (1955).

${ }^{10}$ Manton, Y., J. Exp. Bat., 8, 382 (1957).

${ }^{11}$ Anberg, A., Acta Obstet. Gynec. Scand., 36 (Supp. 2), 1 (195i).

12 Afzelius, B., Z. Zellforsch., 42, 135 (1955).

${ }^{23}$ Fawcett, D. W. Intern. Rev. Cytol., 7, 195 (1958).

${ }^{14}$ Astbury, W. T., and Weibull, C., Nature, 163, 280 (1949).

${ }^{15}$ Nelson, L., Biochim. Biophys. Acta, 27, 634 (1958).

\title{
OBITUARY
}

\section{Prof. Lewis Knudson}

THE death occurred on August 31 of Prof. Lewis Knudson, emeritus professor of botany in Cornell University, Ithaca, New York. Thus ended an association with the New York State College of Agriculture at Cornell University which was in its fifty-first year.

Prof. Knudson was widely known for his work on the aseptic culture of orchid embryos, and his death will be regretted by botanists and plant physiologists around the world. Since his retirement from active teaching and administrative duties in 1952 , at the age of sixty-eight, Prof. Knudson had retained his interest in his research, and, until a very short time before his death at the age of seventy-three, he daily visited the office and laboratory in which he continued to work. He is survived by his wife, two sons and several grandchildren.

The career of Prof. Knudson spans the history of plant physiology in the College of Agriculture at Cornell University, for in 1908 he came from the University of Missouri to work with Prof. Duggar in the then newly established Department of Plant Physiology. Dr. Knudson was to pass his entire and long career at Cornell University, from 1911 when he was awarded the Ph.D. degree, to 1916 when he became professor of botany in the newly constituted Department of Botany under Prof. K. M. Wiegand, to 1941 when he assumed the role of administrative head of the Department on the death of Prof. Wiegand, and until his retirement in 1952 .

During 1919-21 Dr. Knudson spent a year in France, carrying out work at the Sorbonne, attending lectures at the Pasteur Institute, and he also gave lectures in Madrid and Barcelona. His interest in the problems of tropical agriculture took him many times to the countries of Central America.

The effect of the early formative years with Prof. Duggar was long evident and often referred to by Dr. Knudson, even in his later years. An early interest in fungi and in aseptic techniques permeated Prof. Knudson's pioneer work on the growth of whole plants under aseptic conditions, which in turn made feasible his early studies of their organic nutrition and the availability of various carbohydrates for growth. It also permeated his early influence on the growth of excised roots, his work on nitrogen fixation and the nodule-forming organisms, his studies on the germination and nutrition of orchid embryos, and his well-known investigations on mycorrhiza and the aseptic growth of plants which were previously regarded as essentially requiring the mycorrhizal fungus. Prof. Knudson's uses of both orchid embryos and Chlorella to study the facts of mineral nutrition are well known. This dominating interest in the use of aseptic culture methods in the study of plant physiological problems, or to study means of suppressing the growth of fungi as pathogens, survived to his death, for in this area of work his advice was continuelly being sought by industry. Although tissue culture procedures are now commonplace, and the use of uni-algal cultures is frequent in many types of physiological work, one has to recall that Prof. Knudson was among the earliest pioneers in the adoption of these methods. Less widely known, but still noteworthy, was Prof. Knudson's interest in the effects of radiation on chloroplast morphology in ferns.

Another salient characteristic of Prof. Knudson's work and interest was that he was always challenged by the research opportunities inherent in situations fraught with economic consequences. Among his earliest work was an investigation of fermentation processes in the difficult area of tennins; he was challenged by, and often referred to, the commercial production of vanilla; and even up to his death he was working upon a summarized account of the Panama disease of the Gros Michel banana in Central America, a problem to which he had devoted many years. Often far ahead of his time, many of Prof. Knudson's works paved the way so that later researches, made after knowledge and technique had advanced, flourished in areas that he had pioneered.

Perhaps best known for his work on the germination and growth of orchids, Dr. Knudson had a wide circle of correspondents. He advised many growers in his aseptic culture methods of raising embryos to whole plants. One correspondent, not known to him personally, touched him deeply in his later years when he acknowledged his work on orchids by sending an exact replica of an orchid flower set in silver. In 1956, the Federated Garden Clubs of New York State awarded to Dr. Knudson their Gold Medal, which had previously been awarded only to the distinguished botanist and horticulturalist and Dean of the College of Agriculture, Liberty Hyde Bailey.

Prof. Knudson's many friends and students, and those in science and industry who knew of his work, will deeply regret the termination of his long career as botanist and especially plant physiologist.

F. C. Streward 